\title{
Preadmission ESL Testing by Post-Secondary Educational Institutions in Canada
}

\author{
Rosalie J. Banko, Ardiss E. Mackie, and John A. Upshur
}

A survey of administrators in postsecondary institutions probed the procedures and the policies governing preadmission testing of second language ability. Findings indicate that most institutions use some means of measuring ESL but that testing procedures and policies had rarely been subjected to validation studies within the institutions.

This interim report represents the results of the first phase of an ongoing study which addresses the validity of second language tests which are used in Canada to assess the English competency of applicants to post-secondary education. As a preliminary step, 1227 brief questionnaires were sent to registrars, deans and department heads in 177 universities, technical institutes and colleges throughout Canada.

The questionnaires addressed five major concerns:

1. To what extent is ability in English as a second language evaluated prior to admission of applicants?

2. To what extent are English language admissions requirements uniform within institutions? To what extent do English language admission requirements vary according to applicants' prospective field of concentration?

3. What procedures are used for assessing English ability? What are the standards for admissibility? How were these standards derived?

4. At what academic administrative level are admission decisions made?

5. What is the extent of satisfaction with current practices and policies for preadmission English assessment?

The total number of questionnaires sent and usable returns is shown in Table 1. 
Table 1

Summary of Questionnaires Sent and Returned

\begin{tabular}{|c|c|c|c|c|c|c|c|c|c|c|c|c|}
\hline \multirow[b]{3}{*}{ Institutions } & \multicolumn{12}{|c|}{ Academic Administrative Level } \\
\hline & \multicolumn{3}{|c|}{ Registrar } & \multicolumn{3}{|c|}{ Dean } & \multicolumn{3}{|c|}{ Head } & \multicolumn{3}{|c|}{ Total } \\
\hline & $\mathbf{s}$ & $\mathbf{R}$ & $\% \mathbf{R}$ & $\mathbf{s}$ & $\mathbf{R}$ & $\% \mathbf{R}$ & $\mathbf{S}$ & $\mathbf{R}$ & $\% \mathrm{R}$ & $\mathbf{S}$ & $\mathbf{R}$ & $\% \mathbf{R}$ \\
\hline $\begin{array}{l}\text { University } \\
\text { Undergraduate }\end{array}$ & 48 & 40 & 83 & 144 & 87 & 60 & 432 & 191 & 44 & 624 & 318 & 51 \\
\hline $\begin{array}{l}\text { University } \\
\text { Graduate }\end{array}$ & 48 & 23 & 48 & 48 & 24 & 50 & 144 & 65 & 45 & 240 & 112 & 47 \\
\hline $\begin{array}{l}\text { Technical } \\
\text { Institute }\end{array}$ & 18 & 9 & 50 & - & - & - & 54 & 15 & 28 & 72 & 24 & 33 \\
\hline College & 111 & 70 & 63 & - & - & - & 180 & 62 & 34 & 291 & 132 & 45 \\
\hline Total & 225 & 142 & 63 & 192 & 111 & 58 & 810 & 333 & 41 & 1227 & 586 & 48 \\
\hline
\end{tabular}

Note: $\mathrm{S}=$ Sent

$\mathrm{R}=$ Returned

\section{PROCEDURES}

Two procedures were employed in the selection of a sample of respondents. In the first instance, a questionnaire was mailed to all registrars and deans of graduate studies in Canadian universities as well as all registrars in Canadian technical institutions and colleges. For the second procedure, a one-in-K sample was chosen. At each university, three undergraduate deans, three graduate department heads and nine undergraduate department heads were randomly selected. In addition, three department heads in each technical institution and three department heads in 60 colleges were asked to respond. If any institution had less than the required number of administrators, a questionnaire was sent to the existing number.

\section{RESULTS}

Approximately $90 \%$ of Canadian post-secondary institutions require an assessment of the language competency of non-native English appli- 
cants. Although provisions for waiver are available, registrars reported that a single admissions standard is applied in most instances (76\%); in others, the standard varies depending upon the area of study.

The four most widely used assessment procedures are: 1) the Test of English as a Foreign Language (TOEFL); 2) locally developed tests or procedures; 3) the Michigan Test of English Language Proficiency (MTELP); 4) high school English grades. Table 2 lists these tests or procedures for each type of institution. Locally developed tests appear in the table as a single category. When required test scores (or course grades) have been reported, the range of reported scores is given in the table. Reports of standards other than test scores or secondary school grades were predominantly statements to the effect that "the applicant has sufficient language skills to comprehend and produce English required for post-secondary study."

Table 2

Tests, Procedures and Standards for Preadmission English Assessment

\begin{tabular}{|c|c|c|c|c|c|c|c|c|c|c|}
\hline \multirow[b]{2}{*}{ Procedure } & \multicolumn{2}{|c|}{$\begin{array}{c}\text { University } \\
\text { Undergraduate }\end{array}$} & \multicolumn{2}{|c|}{$\begin{array}{l}\text { University } \\
\text { Graduate }\end{array}$} & \multicolumn{2}{|c|}{$\begin{array}{l}\text { Technical } \\
\text { Institute }\end{array}$} & \multicolumn{2}{|c|}{ College } & \multirow{2}{*}{\multicolumn{2}{|c|}{$\begin{array}{cc} & \% \text { Total } \\
& \text { Cita- } \\
\text { Total } & \text { tions }\end{array}$}} \\
\hline & $\begin{array}{l}\text { Cita- } \\
\text { tions }\end{array}$ & Score & $\begin{array}{l}\text { Cita- } \\
\text { tions }\end{array}$ & Score & $\begin{array}{l}\text { Cita- } \\
\text { tions }\end{array}$ & Score & $\begin{array}{l}\text { Cita- } \\
\text { tions }\end{array}$ & Score & & \\
\hline TOEFL & 104 & $500-600$ & 72 & $500-650$ & 4 & $560-580$ & 33 & $500-550$ & 213 & 46 \\
\hline LDT & 37 & - & 15 & - & 6 & - & 19 & - & 77 & 17 \\
\hline MTELP & 34 & $85-95$ & 27 & $80-100$ & 2 & 85 & 7 & 50 & 70 & 15 \\
\hline HSE & 11 & $60-70 \%$ & - & $70 \%$ & 2 & $60 \%$ & 11 & $60-70 \%$ & 24 & 5 \\
\hline
\end{tabular}

Note: TOEFL - Test of English as a Foreign Language

LDT - Locally developed test

MTELP - Michigan Test of English Language Proficiency

HSE - High School English

Note: Responses less than $5 \%$ ot total citations (461) are unlisted.

Note: Citations include multiple responses from the same institution.

The question of how standards were derived was answered overwhelmingly, "experience" $(n=96)$. Other responses, in order, were: consultation with other educational institutions $(n=38)$; recommendations of testing agencies $(n=25)$ and uncertain $(n=20)$. The remaining replies indicated the office, committee, etc. which set the standards for admissibility, but the procedures used by them in deriving those standards were unreported. 
Academic administrative decisions concerning language requirements are made primarily at central levels, for example, by an admissions officer or registrar. However, graduate deans and graduate and college department heads account for more than $40 \%$ of the decision making.

Two aspects of satisfaction were investigated through the questionnaires. The first related to whether deans and department heads in institutions with centralized admissions decisions were satisfied with that locus of decision. The second related to the perception of assessment problems under current practices and procedures. Deans and department heads were asked to respond to the item, "I would prefer more influence from my level." With the exception of department heads in technical institutions $(29 \%)$, no other academic administrative unit indicated a marked preference for greater influence at their level of decision. It should be noted, however, that fewer than half of the questionnaire respondents answered this question.

Responses to the question about the existence of problems in preadmission English assessment are summarized in Table 3. Of the total number of responses made by registrars, deans, and department heads, $33 \%$ indicated an awareness of problems in assessment. Receiving inaccurate information concerning an applicant's English proficiency is the most frequently cited problem $(60 \%)$.

Table 3

Reports by Registrars, Deans and Department Heads of Preadmission Assessment Problems

\begin{tabular}{|lrrrrrr|}
\hline & \multicolumn{3}{c}{ Response } & \multicolumn{3}{c|}{ Type } \\
Institution & Yes & No & \%Yes & a & b & c \\
\hline University Undergraduate & 58 & 116 & 33 & 5 & 32 & 13 \\
University Graduate & 27 & 58 & 32 & 1 & 16 & 10 \\
Technical Institute & 6 & 15 & 29 & 0 & 6 & 3 \\
College & 34 & 64 & 35 & 3 & 23 & 16 \\
\hline Total & 125 & 253 & 33 & 9 & 77 & 42 \\
\hline
\end{tabular}

Problem Types: a - Receive unwanted information

b - Receive inaccurate information

c - Fail to receive desired information

Note: The sum of types does not total the number of 'yes' responses because some respondents have indicated more than one type of problem. Not all respondents answering 'yes' indicated the type of problem, however. 
Respondents were also asked to identify particular assessment problems. Table 4 lists those most frequently cited. The main concern at all levels was that test scores or course grades did not accurately reflect the student's actual English performance.

Table 4

Reports of Preadmission Problems Most Frequently Cited by Institutions

\begin{tabular}{|cccccc|}
\hline \multicolumn{7}{c|}{ Institution } \\
\hline $\begin{array}{c}\text { Problem } \\
\text { Cited }\end{array}$ & $\begin{array}{c}\text { University } \\
\text { Undergraduate }\end{array}$ & $\begin{array}{c}\text { University } \\
\text { Graduate }\end{array}$ & $\begin{array}{c}\text { Technical } \\
\text { Institute }\end{array}$ & College & Totals \\
\hline a & 27 & 8 & 2 & 6 & 43 \\
b & 6 & 6 & - & 1 & 13 \\
c & 5 & 2 & - & 4 & 11 \\
d & 6 & 1 & - & 1 & 8 \\
e & 3 & - & 1 & 3 & 7 \\
\hline Total & 47 & 17 & 3 & 15 & 82 \\
\hline
\end{tabular}

Note: a - TOEFL scores do not reflect true English proficiency.

b - There is a lack of an aural/oral proficiency measure.

c - There is a lack of a writing proficiency measure.

d - Michigan scores do not reflect true English proficiency.

e - High school grades do not reflect true English proficiency.

Although respondents cited a few examples of language competency surpassing test scores, they reported that, in general, a student's language ability was lower than the scores indicated. In addition, some pointed out that many of these students lacked the skills necessary to function effectively in an academic milieu, for example, to follow lectures, take notes, write papers.

It is clear that English language tests are widely used by Canadian institutions as a part of admissions procedures for non-English speaking applicants. It is clear also that measures are used more on faith and reputation than on evidence of validity. Programs of institutional validation are now needed as guides both to selection of tests from among available and forthcoming instruments and to rational development of measures which can satisfy unmet requirements for information about second language abilities. 
The second phase of the project, of which the first is reported here, is the development of criterion measures of academic language proficiency. It is intended that these measures, together with other indexes of academic language functioning may be useful to institutions conducting local validation studies and to those developing and introducing new tests.

\section{THE AUTHORS}

Rosalie J. Banko is Assistant Professor of Education at the University of Alberta where she directs a program in English as a second language. Ardiss E. Mackie teaches in the English Language Training Centre in Daqing, China. At the time this investigation was conducted, she was teaching at the University of Alberta. John A. Upshur is Professor of Applied Linguistics at Concordia University where he teaches courses in language testing and research methods. 